\title{
PHYSICAL DEVELOPMENT AND EATING HABITS OF A TEENAGE GROUP FROM DIMITRIE CANTEMIR HIGH SCHOOL IN IASI
}

\author{
Adriana ALBU, Irina ABDULAN, Catalin Dragos GHICA \\ Grigore T. Popa University of Medicine and Pharmacy, Iasi, Romania
}

Corresponding author:, Catalin Dragos Ghica, e-mail: dragos.ghica@yahoo.ro

DOI: $10.38045 /$ ohrm.2021.4.08

CZU: [613.96+613.2]-053.7(498-21)

Keywords: physical development, eating habits, high school students.

Cuvinte cheie: dezvoltare fizică, obiceiuri alimentare, elevi de liceu.
Introduction. Eating habits are formed in the first years of life and sometimes persist throughout lifetime. It is necessary to develop coherent nutritional educational programs to guide adolescents towards a healthy diet.

Material and methods. The study was conducted on a group of 194 students from the ninth and the twelfth grade from Dimitrie Cantemir High School in Iasi. These young people were evaluated for their physical development with the help of body mass index and eating habits. Eating habits were assessed on the basis of a weekly food intake questionnaire. The processing of the results was carried out by the Pearson test.

Results. Physical development was mainly at normal values (68.55\%). There were 19.07\% underweight students but also $12.37 \%$ young people with obesity. Milk was present in menus especially 2-3 times (35.05\%) or 1 time (25.77\%) per week, with insignificant differences by class and sex. Chicken meat was mainly consumed 2-3 times a week (42.78\%) with insignificantly differing in classes, but significant in gender $(p<0.001)$. Vegetables were consumed especially 2-3 times (30.92\%) per week or daily (28.35\%). Sweets were consumed mainly on a daily basis (29.89\%) or 2-3 times (26.28\%) per week.

Conclusions. The eating habits of students surveyed were different in girls than in boys, an aspect that draws attention to young females for whom identification with the current ideal of beauty is essential.

DEZVOLTAREA FIZICĂ ȘI OBICEIURILE ALIMENTARE ALE UNUI LOT DE ADOLESCENTTI DE LA LICEUL „DIMITRIE CANTEMIR” DIN IAȘI

Introducere. Obiceiurile alimentare se formează în primii ani de viață și uneori persistă dea lungul vieții. Este necesar să se dezvolte programe educaționale nutriționale coerente pentru a ghida adolescenții către o dietă sănătoasă.

Material și metode. Studiul a fost realizat pe un grup de 194 de elevi din clasele a IX-a și a XII-a de la Liceul "Dimitrie Cantemir" din Iași. La acești tineri a fost apreciată dezvoltarea fizică cu ajutorul indicelui de masă corporal și al obiceiurilor alimentare, care au fost evaluate pe baza unui chestionar săptămânal privind consumul de alimente. Prelucrarea rezultatelor a fost efectuată cu ajutorul testului Pearson.

Rezultate. Dezvoltarea fizică s-a încadrat, mai ales, la valori normale (68,55\%). S-au identificat 19,07\% elevi subponderali și 12,37\% tineri cu obezitate. Laptele a fost prezent în meniuri în special de 2-3 ori $(35,05 \%)$ sau de 1 dată $(25,77 \%)$ pe săptămână, cu diferențe nesemnificative, în funcție de clasă și de sex. Carnea de pui s-a consumat în principal de 2-3 ori pe săptămână (42,78\%), cu diferențe nesemnificative pe clase, dar semnificative după sex $(p<0,001)$. Legumele s-au consumat în special de $2-3$ ori $(30,92 \%)$ pe săptămână sau zilnic (28,35\%). Dulciurile s-au consumat mai ales zilnic (29,89\%) sau de $2-3$ ori $(26,28 \%)$ pe săptămână.

Concluzii. Obiceiurile alimentare ale elevilor chestionați diferă la fete față de băieți, aspeci care atrage atenția asupra adolescentelor pentru care identificarea cu idealul actual de frumusețe este esențială. 


\section{INTRODUCTION}

A balanced diet will make a decisive contribution to maintaining students' health and ensuring normal growth/development. In high school students, nutrition must be carefully studied because it appears the identification with the current ideal of beauty represented by the thin young woman and the young man with developed muscle masses. Normal body appearance but not overlapping with these desires can become a factor of dissatisfaction and recourse to inadequate diets (1). There are many situations in which adolescents have problems perceiving their own body, which can expose them to the risk of serious health problems. They have a normal weight or are even underweight but they are considered too fat so they keep on to various regimes that are inappropriate (2). Most problems occur in teenage girls, so they need to be closely monitored in and out of school (3).

Eating habits are formed within the family in the first years of life and sometimes persist throughout lifetime. It is important to know the specifics of the population's diet and intervention when needed. In the Romanian population there is a strong anchoring to traditions, so that in most studies the differences calculated by age group and even sex is statistically insignificant (4). These are aspects that need to be known and taken into account by nutritionists when trying to change the eating habits.

Changing eating habits must start from a complex of factors represented by the appropriate nutritional recommendations, the socio-economic situation of the family, the social context and even the current mental state. A study conducted on adolescents in the US reported interesting answers such as eating unhealthy food in a certain social settings (at parties), in moments of joy, anger, stress (5).

Another aspect that must be carefully studied and evaluated by specialists is the absence of consumption of a certain food. It is important to try to evaluate the reasons why some foods are not consumed, as they may be of economic origin, family habits or food displeasure (6). Nutritionists must pay attention to this aspect because you cannot direct the young person to consume food that he does not like in terms of taste.

The objectives of the study: To evaluate the physi cal development of high school students; to assess the differences according to the age and taking into account the particularities of the growth process; to study the students' eating habits; to evaluate the conditions in which they change starting from the age group and sex of the person.

\section{MATERIAL AND METHODS}

The study group consisted of 194 students from Dimitrie Cantemir High School in Iasi. These were high school students from the 12th grade (82 young people) and the 9 th grade (112 students). The distribution by sex was unequal, with 126 girls (64.94\%) and 68 boys (35.05\%) being surveyed. These young people were appreciated for their physical development and their eating habits were assessed. Physical development was assessed using the Body Mass Index using the special student computer (7). The weight between the student and his height was reported and the interpretation of the results was made according to age and sex. Values fall to a level of underweight, normal or overweight/obesity.

The assessment of eating habits was performed using a weekly food frequency questionnaire. The weekly intake of milk, chicken, meat dishes, vegetables and sweets was appreciated. It goes on the variety of an intake of: never/1 time a week/2-3 times a week/4-6 times a week and daily. The results were processed using the Pearson chi square test.

\section{RESULTS}

The study focused towards the students 'physical development and their eating habits.

Physical development was appreciated starting from the values of body weight and height, which allows the calculation of the body mass index. The values must be carefully interpreted especially in the 9 th grade students where the growth process is still intense. Most students (68.55\%) refer to normal values, which is a positive result. There were underweight young people (19.07\%) but also overweight/obese (12.37\%). It is necessary to follow these students carefully but without interfering, at least in a first stage (tab. 1).

The differences calculated between the classes of students in terms of weight categories defined by BMI were statistically insignificant $(p>0.05, f=2$, $\chi^{2}=0.782$ ). Depending on the gender of the stu- 
dents, the differences were statistically significant at a $p<0.01\left(f=2, \chi^{2}=11,759\right)$, demonstrating a greater concern of girls for body appearance.

Eating habits were appreciated by studying the weekly intake of food of animal origin (milk, chicken, meat dishes) and vegetables (vegetables and sweets).

Milk is a complete food that must be daily con sumed according to the requirements of rational nutrition. Unfortunately, the balanced intake was found in $16.49 \%$ of students and $13.91 \%$ of adolescents with milk consumption of 4-6 times a week. Most students admit the presence of milk in menus only 2-3 times (35.05\%) or once $(25.77 \%)$ per week, while $8.76 \%$ of them does not consume milk at all (tab. 2).

Table 1. Characteristics of the study group according to the values of the body mass index.

\begin{tabular}{|c|c|c|c|c|}
\hline Weight Category & Underweight & Normal & Overweight / obesity & Total \\
\hline \multicolumn{5}{|c|}{ Data distribution by class } \\
\hline 12th grade & 16 & 54 & 12 & 82 \\
\hline 9th grade & 21 & 79 & 12 & 112 \\
\hline Total (no.) & 37 & 133 & 24 & 194 \\
\hline$\%$ & 19.07 & 68.55 & 12.37 & \\
\hline \multicolumn{5}{|c|}{ Data distribution by gender } \\
\hline Female & 32 & 83 & 11 & 126 \\
\hline Male & 5 & 50 & 13 & 68 \\
\hline
\end{tabular}

Table 2. Frequency of milk intake in students' menus.

\begin{tabular}{|c|c|c|c|c|c|}
\hline $\begin{array}{c}\text { Frequency of } \\
\text { food intake }\end{array}$ & Never & Once a week & 2-3 times a week & 4-6 times a week & Once a day \\
\hline \multicolumn{6}{|c|}{ Data distribution by class } \\
\hline 12th grade & 9 & 23 & 26 & 9 & 15 \\
\hline 9th grade & 8 & 27 & 42 & 18 & 17 \\
\hline Total (no.) & 17 & 50 & 68 & 27 & 32 \\
\hline$\%$ & 8.76 & 25.77 & 35.05 & 13.91 & 16.49 \\
\hline \multicolumn{6}{|c|}{ Data distribution by gender of students } \\
\hline Female & 14 & 37 & 38 & 18 & 19 \\
\hline Male & 3 & 13 & 30 & 9 & 13 \\
\hline
\end{tabular}

The calculated differences were insignificant by classes viz. $p>0.05, f=4, \chi^{2}=2.419$, whereas depending on the students' gender $-p>0.05, f=4$, $\chi^{2}=6.691$, which shows the presence of similar eating habits.

Chicken meat is rich in protein, but low in fat providing a low-calorie intake. In this context, specific attention should be paid to the consumption of poultry in girls.

The most prevalent chicken intake was 2-3 times a week (42.78\%), a result that is not worrying because other types of meat are consumed. A percentage of 8.24 of the students declared a daily consumption of meat, and $1.03 \%$ of them did not eat meat at all. The differences assessed depending on classes were statistically insignificant ( $p>0.05, f=4, \chi^{2}=8.737$ ) and showing similar eating habits in the families of the young people in the study group (tab. 3).
The differences assessed depending on gender were statistically significant at a $p<0.001(f=4$, $\chi^{2}=29.272$ ) and showed an increased consumption of chicken meat among girls.

Meat dishes are widely used today due to the ease with which they can be added to menus. The prevalent intake was 2-3 times a week (31.95\%), daily intake $(12.88 \%)$ as well as not eating meat at all (9.28\%) (tab. 4).

The differences assessed depending on class distribution were statistically insignificant ( $p>0.05$, $f=4, \chi^{2}=2.078$ ) and showing similar eating habits according to the age group. Girls consumed meat dishes less often, the differences calculated according to the gender of the students being statistically significant at a $\mathrm{p}<0.05\left(\mathrm{f}=4, \chi^{2}=11.976\right)$.

Vegetables have a low-calorie value providing little protein and fat to the human body. In most cases they are present in menus 2-3 times a week 
$(30.92 \%)$ or daily $(28.35 \%)$. These products are rich in carbohydrates, minerals and vitamins; thus, they should be included in a balanced diet. (tab. 5).

Table 3. Consumption of chicken meat.

\begin{tabular}{lccccc}
\hline $\begin{array}{l}\text { Frequency of } \\
\text { food intake }\end{array}$ & Never & Once a week & 2-3 times a week & 4-6 times a week & Once a day \\
\hline 12th grade & 1 & Data distribution by class & & \\
\hline 9th grade & 1 & 10 & 34 & 29 & 8 \\
\hline Total (no.) & 2 & 30 & 49 & 24 & 16 \\
\hline$\%$ & 1.03 & 40 & 83 & 27.32 & 8.24 \\
\hline & 1 & Data distribution by gender & & 16 \\
\hline Female & 1 & 29 & 44 & 36 & 0 \\
\hline Male & 1 & 11 & 39 & 17 & \\
\hline
\end{tabular}

Table 4. Frequency of consumption of meat dishes.

\begin{tabular}{lccccc}
$\begin{array}{l}\text { Frequency of } \\
\text { food intake }\end{array}$ & Never & Once a week & 2-3 times a week & 4-6 times a week & Once a day \\
\hline \multicolumn{7}{c}{ Data distribution by class } \\
\hline 12th grade & 9 & 22 & 23 & 18 & 10 \\
\hline 9th grade & 9 & 31 & 39 & 18 & 15 \\
\hline Total (no.) & 18 & 53 & 62 & 36 & 25 \\
\hline \% & 9.28 & 27.32 & 31.95 & 18.55 & 12.88 \\
\hline \multicolumn{7}{r}{} & 17 & Data distribution by gender & \\
\hline Female & 1 & 15 & 33 & 23 & 15 \\
\hline
\end{tabular}

Table 5. Presence of vegetables in students' menus.

\begin{tabular}{|c|c|c|c|c|c|}
\hline $\begin{array}{l}\text { Frequency of } \\
\text { food intake }\end{array}$ & Never & Once a week & 2-3 times a week & 4-6 times a week & Once a day \\
\hline \multicolumn{6}{|c|}{ Data distribution of results by class } \\
\hline 12th grade & 3 & 11 & 19 & 22 & 27 \\
\hline 9th grade & 2 & 14 & 41 & 27 & 28 \\
\hline Total (no.) & 5 & 25 & 60 & 49 & 55 \\
\hline$\%$ & 2.57 & 12.88 & 30.92 & 25.25 & 28.35 \\
\hline \multicolumn{6}{|c|}{ Data distribution by gender } \\
\hline Female & 4 & 15 & 34 & 29 & 44 \\
\hline Male & 1 & 10 & 26 & 20 & 11 \\
\hline
\end{tabular}

The calculated differences in vegetable intake were statistically insignificant by classes ( $p>0.05$, $\left.f=4, \chi^{2}=4,704\right)$ but also by gender $(p>0.05, f=4$, $\left.\chi^{2}=7,812\right)$.

Sweets are rich in carbohydrates providing an in creased calorie intake. However, they must be present in balanced quantities within the diet. The prevalent daily intake is $29.89 \%$ and $4-6$ times a week $-25.25 \%$. On the other hand, $2.06 \%$ of students denied any consumption of sweets (tab. 6).

The differences assessed by classes were statistically insignificant $\left(p>0.05, f=4, \chi^{2}=6.866\right)$ but those calculated according to the gender were significant at a $p<0.05\left(f=4, \chi^{2}=12.557\right)$, in girls the daily intake was dominant. 
Table 6. Frequency of sweets consumption.

\begin{tabular}{|c|c|c|c|c|c|}
\hline $\begin{array}{l}\text { Frequency of } \\
\text { food intake }\end{array}$ & Never & Once a week & 2-3 times a week & 4-6 times a week & Once a day \\
\hline \multicolumn{6}{|c|}{ Data distribution by class } \\
\hline 12th grade & 0 & 15 & 23 & 16 & 28 \\
\hline 9th grade & 4 & 17 & 28 & 33 & 30 \\
\hline Total (no.) & 4 & 32 & 51 & 49 & 58 \\
\hline$\%$ & 2.06 & 16.49 & 26.28 & 25.25 & 29.89 \\
\hline \multicolumn{6}{|c|}{ Data distribution by gender } \\
\hline Female & 4 & 15 & 34 & 29 & 44 \\
\hline Male & 1 & 10 & 26 & 20 & 11 \\
\hline
\end{tabular}

\section{DISCUSSIONS}

Given the media pressure focused on overweight students, often neglecting the underweight, in recent years, several studies have investigated the physical development and eating habits of adolescents.

In our study, students' physical development was dominant at normal values, which is a positive aspect.

The comparative evaluation carried out on adolescents in Bucharest in 2010 and 1977 highlights an interesting aspect represented by the existence of a small percentage of young people with obesity. In 2010 the percentage of obese students was $5.5 \%$ for girls and $8.62 \%$ for boys, and in $19774.75 \%$ for girls and $7.27 \%$ for boys (8).

In a group of young people from Saudi Arabia, the percentage of young people with obesity was $36.35 \%$, and those with obesity grade III is $43.86 \%$ (9).

Self-perception of body weight is also important because there are people who are overweight but consider themselves normal and thin people who consider themselves obese. Students in Iran are $22.25 \%$ overweight and $4.41 \%$ obese, normal weight being assessed in only $53.08 \%$ of cases (10).

It is important to appreciate correctly the situation that is very different from one geographical area to another, from one family to another. Knowledge of the family situation sometimes becomes essential because many studies reveal the link between the body mass index of mother and child, especiallyof girls. Mothers become role models for weight loss and dietary restrictions, which is not a positive thing (11).

The evaluation of eating habits is therefore neces sary but also of the possibility of changing them. In the population of the northern part of Romania there is a strong anchoring to traditions (4).

According to the rules of rational nutrition, a daily milk intake is recommended, which was reported only in a few students from the study group.

Young people in Austria recognize an average weekly milk intake of $2.2 \pm 1.0$, which is insufficient but somewhat similar to the results of our study (12). Young people in Sudan admit a milk intake especially on a daily basis (37.1\%) but there are also $20.5 \%$ negative responses (13). In the students of Rawalpindi, the consumption of milk is daily in $44.9 \%$ of them but absent in $32.6 \%$ of young people (14). Young people in Iran admit a daily milk intake in $19.39 \%$ of cases but in $35.90 \%$ of them milk consumption is absent (10). There are differences that must be known and carefully interpreted.

Chicken meat is present in the menus of the surveyed students, especially 2-3 times a week.

Consumption 2-3 times a week is also recognized by young people in Rawalpindi (50.4\%), while in Sudan chicken is consumed mainly once a week (42.9\%) (14). The results obtained are important because they highlight different eating habits in different populations.

Meat dishes are high in fat so it is easy to understand the reaction of girls concerned about their body appearance.

Vegetables are foods that have a low nutritional value due to their low protein and fat content. We must insist on normal intake while avoiding exaggerations, especially in girls. In terms of nutritional value there are no major differences between types of vegetables but it is important in terms of taste and nutritional education. There 
are cases in which certain vegetables are not eaten because the taste, color or smell is not accepted, they are not eaten in the family, they are not consumed by someone in the family or the method of preparation is not known (15). Modern nutrition addresses more and more problems, not just the simple answer to how many times a week a type of food is consumed.

Sweets must be present in the menus due to the intake of carbohydrates they provide. The nervous system and red blood cells use them as the only source of energy so they are needed but in adequate amounts. The dominant contribution to the students in the study group is daily or 4-6 times a week, with a high percentage of girls giving this answer. Adolescents in Austria admit an average consumption of $2.6 \pm 1.1$ which is totally insufficient (12). Young people in Iran have a dominant intake of 3-6 times a week (46.26\%) with $10.35 \%$ negative responses (10).

It is important to evaluate the diet of young people for the correct orientation of nutritional education programs.

\section{CONCLUSIONS}

1. The physical development and eating habits of the students were evaluated, which allows a real knowledge of the situation on the field.

2. Physical development was prevailing at normal values $(68.55 \%)$ with a small percentage of underweight (19.07\%) or obese (12.37\%) students. Depending on the gender of the students, the differences were statistically significant, demonstrating a greater concern of girls for body appearance. These results must be carefully interpreted because the students in the ninth grade are still in full process of growth and development.

3. The eating behavior of the investigated students revealed inappropriate aspects because there were quite a few situations in which young people admitted that they do not consume a certain group of foods at all (milk $-8.76 \%$ of students, chicken $-8.24 \%$, meat dishes $-9.28 \%$ ).

4. Intakes by food groups showed statistically insignificant differences by classes, indicating the presence of similar eating habits.

5. Statistically significant differences were identified by gender, with girls having a high intake of chicken and sweets and a low intake of meat dishes.

6. Such studies are essential for maintaining the health of students and for educating their eating habits.

\section{CONFLICT OF INTERESTS}

The authors declare no conflict of interest.

\section{REFERENCES}

1. Abălașei B, Trofin F. Considerations on the correlation between real body and body image. Timisoara Physical Education and rehabilitation Journal. 2016;9(16):7-12.

2. Bandeira Lima FE, de Oliveira NM, Francisquinho ML, Coco MA, Bandeira Lima F, Lima WF, et al. Prevalence of body mass index and the body image in adolescents of both sex. Ec Psychology And Psychiatry. 2019; 8(10):1010-16.

3. Chung WS, Shin KO, Bae JY. Gender differences in body image misperception according to body mass index, physical activity and health concern among Korean University students. Journal of Men's Health. 2019,15(1):e1-e9.

4. Albu A, Moraru C, Hodorca RM. The evaluation of some eating habits at a group of teenagers studying at Dimitrie Cantemir high school of Iasi.
Procedia - Social and Behavioral Sciences. 2015; 197:1947-51.

5. Abraham S, Noriega BR, Shin JY. College students eating habit and knowledge of nutritional requirement. J Nutr Hum Health.2018; 2(1):13-17.

6. Demirici N, Toptaș Demirici P. The determinant of physical activity, nutrition and self-sufficiency level of sedentary individuals of fitness club member. Pedagogics Psychology. 2018, 05:237245.

7. Calculator IMC pentru copii și adolescenți. Available from: https://www.nutritiepediatrica. ro/calculator-imc/ [Accessed 17th Apr 2021].

8. Baciu A. Anthropological-medical aspects of feeding behavior of children in modern society. Review of Global Medicine and Healthcare Research. 2011;2(1):79-99. 
9. Varghese A, Kaukab A. Influence of physical activity, body mass index on perceived physical self-concept among undergraduate students of Saudi Arabia. Int J Parm Investigation. 2019, 9(4):210-214.

10. Shahraki-Sanavi F, Rakhshani F, AnsariMoghaddam A, Mohammadi M. Associations of physical activity and sedentary behaviors with dietary behaviors among mid-adolescent female students in the southeast of Iran. Bioscience biotechnology Research Communication, Medical Communication.2017, 10(4):739-745.

11. Meraz MG, Guzman Saldaña RME, LópezRodriguez G, Galván M. Relationship between maternal and children body mass index in four educational sistem in Hidalgo Mexico. Rev EspNutr Hum Diet. 2019,23(4):252-260.

12. Drenowatz C, Greier K. Association of sports par- ticipation and diet with motor competence in Austrians middle school students. Nutrients MDPI. 2018,10(1837):1-11.

13. Misaa MAA, Somya GSM, Siham MOG. Assessment of nutritional status of the adolescents (15-18 yrs) studying in secondary schools in Elhafeir AreaDangle locality-northern state 2018, Indian Journal of Applied Research, Epidemiology. 2018, 8(5):1-5.

14. Naseer O, Mahmood F, Fazil M, Bilal S, Kulsoom A, Hamid S. Eating habits of adolescent students. Journal of Rawalpindi Medical College. 2018, 22(4):357-360.

15. Raggio L, Gambara A. Study of the reason for the consumption of each type of vegetable within a population of school-aged children. BMC Public Health.2018, 18(1163):1-11.

Date of receipt of the manuscript: $30 / 07 / 2021$

Date of acceptance for publication: 30/09/2021

Adriana ALBU, ORCID ID: 0000-0002-9445-4331, SCOPUS Author ID: 35733298200

Irina ABDULAN, ORCID ID: 0000-0001-9254-6809, Web of Science Researcher ID: AAA-3089-2020, SCOPUS Author ID: 44960909800

Catalin Dragos GHICA, ORCID ID: 0000-0002-9721-6582 